\section{Discourse with Iran}

\section{Academic freedom is under threat, again.}

| / hould you wake up one day to find your wife or child or parent in the hands of the secret police in a country that routinely violates the rule of law, you will likely choose quiet probing over publicity. You have no recourse to law or courts. You fear publicity may make things worse. You believe, almost always wrongly, that if you work quietly, use the contacts you have and wait reasonably, the nightmare will be over."

In this plea in the Los Angeles Times, Shaul Bakhash, a specialist in Middle Eastern history at George Mason University in Fairfax, Virginia, eloquently captures the predicament of prisoners and their families caught up in political conflicts. Bakhash's wife Haleh Esfandiari, director of the Middle East Program at the Woodrow Wilson International Center for Scholars in Washington DC, is one of three US-Iranian researchers jailed in Iran on charges of plotting a 'velvet revolution'.

Bakhash has broken his silence, and is backing protests by academic and human-rights organizations as the best hope for justice for the jailed researchers (see page 890). Scientists should support such efforts in every way they can, to ensure that Iran's rulers know the world is watching.

Keeping the cases in the spotlight is also helpful in pressing diplomats to make resolution of the cases a priority. The importance of this has been demonstrated in the case of six health workers condemned to death in Libya. Their appeal will be judged today by Libya's
Supreme Court — one step in a delicate endgame, which observers hope will lead to their prompt release.

In the current climate of mutual suspicion between the United States and Iran, simply protesting innocence is not enough. Academics should also demand that Iran respect its commitments to human-rights treaties by making public its evidence against the three, as it has so far failed to do, and allowing them access to lawyers.

Iranian academics are also suffering discrimination abroad as a result of Iran's stand-off with the international community and in particular with the United States. Although the difficulties of getting visas for entry to the "Scientists should support such efforts in every way they can, to ensure that Iran's rulers know the world is watching."

United States have eased, Iranians tell of new problems in Canada and Australia, and complain of being shunned in international collaborations as being part of a 'rogue state'.

The arrests have led to calls for a deepening of Iran's academic isolation (to be fair, these calls are based more on legitimate concerns about safety of travel than on a desire to boycott Iran). This approach has also reared its head in Britain, where the annual meeting of the University and College Union voted on 30 May to ask its branches to consider a proposal to boycott Israeli academic institutions. They should firmly reject this proposal (see Nature 417, 1; 2002).

Where colleagues suffer as a result of political tensions, researchers everywhere should be engaging more, not less, in constructive reform and cooperation - through increased support, for example, of collaborative projects in the regions concerned.

\section{An end in sight}

\section{Better days ahead for flagship regulator.}

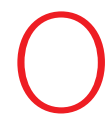
ne of the great paradoxes of American life is that of the nation's self-image as the "land of the free" and the reality of living in one of world's more tightly regulated societies.

If John Wayne were to stroll down certain Main Streets at noon today, he would not just risk being arrested for jay-walking and carrying an exposed weapon; he might also face charges for smoking tobacco in the saloon the previous evening, or lighting a bonfire in his own back garden. And quite right, too. Sensible regulation has become an integral part of the American way of life.

The European Union may talk a good talk when it comes to rules and regulations, but the truth is that effective measures to clean up water and air - to give just two examples - were pioneered in the United States and are tirelessly enforced there by federal agencies of formidable power and reach.

The largest and most influential of these is the Environmental Protection Agency (EPA), which was founded by President Richard Nixon in 1970 during the environmental movement's first, noisy spring (see page 892). Today, the EPA is an US\$8-billion agency, and its 17,000 staff carry an array of legal and technical expertise, and legislative authority, that sister agencies abroad can barely dream of.

US President George W. Bush and a number of his key supporters abhor the EPA with an unusual venom. However, it has never been expedient, or even polite, for them to say as much. Furthermore, under a political system renowned for creating budgetary deficits, it has not been feasible for them to actually cut back the agency to any significant extent.

Instead, since 2000, parts of the EPA have existed in a peculiar limbo. Inside the ironically named Ronald Reagan Building and other agency premises, lawyers in some sections are paid handsome wages to do very little, rather than pursue major regulatory infringements that - they know full well - their politically appointed bosses will not follow through in court. 'Commissioners' from the White House Office of Management and Budget or the Council on Environmental Quality roam the corridors, making sure no one is getting too zealous, and reporting back to regulated industries on things to dodge or cover up.

Thankfully, these creepy characters lack the authority to actually fire the conscientious lawyers and scientists who staff the EPA. Like their colleagues at other regulatory agencies, notably the Food and Drug Administration (where political interference, although present, has been less brazen), these people are lying low, aware that no future administration, Republican or Democrat, is likely to hold the agency's underlying mission in such contempt. With a more supportive Congress, and a Supreme Court asserting the agency's power to regulate carbon emissions, an unfortunate period in the EPA's history is drawing to a close. 